\title{
PENGARUH GAYA KEPEMIMPINAN TRANSFORMASIONAL KEPALA SEKOLAH, IKLIM SEKOLAH DAN KOMITMEN PROFESIONAL GURU TERHADAP KINERJA GURU (STUDI KASUS DI MTS MA'ARIF NU KABUPATEN BANYUMAS)
}

\author{
Ahmad Adzkiya*1 \\ ${ }^{1}$ Program Pascasarjana Magister Akuntansi, Fakultas Ekonomi dan Bisnis, Universitas Jenderal \\ Soedirman \\ *E-mail corresponding author: adzkiyaa@gmail.com
}

\begin{abstract}
ABSTRAK
Penelitian ini mengambil judul: Pengaruh Gaya Kepemimpinan Transformasional Kepala Sekolah, Iklim Sekolah dan Komitmen Profesional terhadap Kinerja Guru (Studi Kasus di MTs Ma'arif NU Kabupaten Banyumas). Tujuan penelitian ini adalah untuk mengetahui pengaruh gaya kepemimpinan transformasional Kepala Sekolah, Iklim Sekolah dan Komitmen Profesional terhadap Kinerja Guru (Studi Kasus di MTs Ma'arif NU Kabupaten Banyumas).

Populasi dalam penelitian ini adalah seluruh guru di MTs Ma'arif NU Kabupaten Banyumas yang berjumlah 662 orang. Jumlah responden yang diambil dalam penelitian ini sebanyak 250 responden. Teknik pengambilan sampel menggunakan teknik random sampling. Berdasarkan hasil penelitian dan analisis data dengan menggunakan SPSS versi 24.00 for windows menunjukkan bahwa: 1) Gaya kepemimpinan transformasional sekolah berpengaruh positif dan signifikan terhadap iklim sekolah di MTs Ma'arif NU Kabupaten Banyumas. 2) Gaya kepemimpinan transformasional kepala sekolah berpengaruh positif dan signifikan terhadap komitmen profesional guru MTs Ma'arif NU di Kabupaten Banyumas. 3) Iklim sekolah berpengaruh positif dan signifikan terhadap kinerja guru MTs Ma'arif NU di Kabupaten Banyumas. 4) Komitmen profesional berpengaruh positif dan signifikan terhadap kinerja guru MTs Ma'arif NU di Kabupaten Banyumas. 5) Gaya kepemimpinan transformasional kepala sekolah berpengaruh positif dan signifikan terhadap kinerja guru di MTs Ma'arif NU Kabupaten Banyumas. Implikasi dari kesimpulan diatas adalah dapat dijadikan sebagai bahan rujukan dan sebagai masukan bagi para guru khususnya di MTs Ma'arif NU Kabupaten Banyumas untuk meningkatkan kualitas kinerja guru, sehingga kinerja guru menjadi lebih baik dan komitmen guru. dalam mengajar lebih profesional.
\end{abstract}

Kata Kunci: Gaya Kepemimpinan Transformasional, Kinerja, Iklim Sekolah, Komitmen Profesional

\footnotetext{
ABSTRACT

This research takes the title: The influence of the Principal's transformational leadership style, School Climate and Professional Commitment on Teacher Performance (Case Study in MTs Ma'arif NU Banyumas Regency). The purpose of this study was to determine the effect of the transformational leadership style of School Principals, School Climate and Professional Commitments on Teacher Performance (Case Study in MTs Ma'arif NU Banyumas Regency).

The population in this study were all teachers in MTs Ma'arif NU Banyumas Regency which were 662 people. The number of respondents taken in this study was 250 respondents. The sampling technique uses random sampling techniques. Based on the results of research and data analysis using SPSS version 24.00 for windows, it shows that: 1) The transformational leadership style of the school has a positive and significant effect on the school climate in MTs Ma'arif NU Banyumas Regency. 2) The principal's transformational leadership style has a positive and significant effect on the professional commitment of MTs Ma'arif NU teachers in Banyumas Regency. 3) School climate has a positive and significant effect on the performance of MTs Ma'arif NU teachers in Banyumas Regency. 4) Professional commitment has a positive and significant effect on the performance of MTs Ma'arif NU teachers in Banyumas Regency. 5) The principal's transformational leadership style has a positive and significant effect on teacher performance in MTs Ma'arif NU Banyumas Regency. The implication of the conclusion above is that it can be used as a reference material and as an input for teachers especially in MTs Ma'arif NU Banyumas Regency to improve the quality of teacher performance, so that teacher performance becomes better and the commitment of teachers in teaching is more professional.
} 
Keywords: Transformational Leadership Style, Performance, School Climate, Professional Commitment

\section{PENDAHULUAN}

Guru merupakan garda terdepan dan memiliki posisi sentral dalam suksesnya pelaksanaan proses pendidikan. Guru merupakan salah satu faktor penentu tinggi rendahnya kualitas. Setiap usaha peningkatan pendidikan perlu dibarengi dengan peningkatan guru dalam segi jumlah maupun kualitasnya.

Salah satu indikator kualitas pendidikan ditentukan oleh kinerja guru. Indikator kinerja guru terlihat dari rasa tanggungjawab dalam menjalankan amanah, profesi yang diemban dan rasa tanggungjawab moral. Kinerja guru akan terlihat kepada kepatuhan dan loyalitas di dalam menjalankan tugas keguruan di dalam kelas dan tugas kependidikan di luar kelas.

Sikap tersebut akan diiringi pula dengan rasa tanggungjawab mempersiapkan segala perlengkapan pembelajaran sebelum proses pembelajaran dilaksanakan. Kinerja guru memiliki kriteria tertentu. kinerja guru dapat diukur dan dilihat berdasarkan kriteria kompetensi yang harus dimiliki oleh setiap guru (Setiyati, 2014).

Menurut Hasibuan sebagaimana dikutip dari Sujak (1999) dan Sutiadi (2003) mengungkapkan bahwa kinerja adalah suatu hasil kerja yang dicapai seseorang dalam melaksanakan tugas-tugas yang menjadi kewajibannya yang yang didasarkan pada kecakapan pengalaman dan kesungguhan serta waktu. Ada 3 faktor yang mempengaruhi kinerja antara lain: 1) individu (kemampuan kerja), 2) usaha kerja (keinginan untuk bekerja) serta 3) dukungan organisasional (kesempatan untuk bekerja). Dengan perkataan lain kinerja adalah hasil kerja yang diperoleh seseorang dalam melaksanakan tugas yang diberikan kepadanya sesuai dengan kriteria yang sudah ditetapkan.

Seorang guru sangat perlu memiliki kinerja yang tinggi untuk meningkatkan hasil pembelajaran. Sebagai ujung tombak dalam pendidikan guru memiliki peran penting, para peserta didik tidak mungkin dapat belajar sendiri tanpa ada bimbingan dari guru yang memiliki kinerja yang baik. Sebab, peserta didik pada hakikatnya hanya dapat belajar dengan baik jika guru telah mempersiapkan lingkungan yang baik dan positif untuk belajar, misalnya media dan metode pembelajaran. Seorang guru harus dapat melaksanakan kewajibannya dalam pembelajaran mulai dari perencanaan sampai kepada tindak lanjut dari kegiatan mengajar yang dilakukan.

Banyak faktor antara lain, salah satunya adalah gaya kepemimpinan. Berdasarkan penelitian yang dilakukan oleh Tampi (2014) menunjukan bahwa gaya kepemimpinan berpengaruh positif terhadap kinerja karyawan. Penelitian serupa juga dilakukan oleh Setiyani (2014) yang menunjukan bahwa gaya kepemimpinan berpengaruh positif dan signifikan terhadap kinerja guru.

Kepala sekolah, dalam memanajemen pendidikan mempunyai tugas membuat keputusan. Membuat keputusan adalah aspek penting yang menuntut kemampuan manajerial untuk menyatukan dan mengembangkan elemen yang relevan dalam kondisi dan situasi lembaga pendidika secara keseluruhan. Berdasarkan penelitian yang dilakukan oleh Saputra dkk (2015) menunjukan bahwa terdapat pengaruh yang positif dan signifikan gaya kepemimpinan kepala sekolah terhadap kinerja Guru SMA Negeri Sederajat di Kecamatan Balik Bukit Lampung Barat.

Selain gaya kepemimpinan, faktor lain yang mempengaruhi kinerja guru adalah budaya sekolah. Budaya sekolah atau iklim sekolah menggambarkan suasana dan hubungan kerja guru dengan sesama guru, guru dengan kepala sekolah, guru dengan tenaga kependidikan dan dinas dilingkungan kerja yang merupakan wujud lingkungan kerja yang kondusif.

Menurut Hasanah (2010) Suasana yang kondusif sangat dibutuhkan Guru dan kepala sekolah untuk melaksanakan pekerjaannya dengan lebih efektif. Budaya sekolah dapat digambarkan melalui sikap saling mendukung (supportive), tingkat persahabatan (collegial), tingkat keintiman (intimate), serta kerjasama (cooperative). Kondisi yang terjadi atas keempat dimensi budaya sekolah tersebut diharapkan berpotensi meningkatkan kinerja Guru.

MTs adalah lembaga pendidikan yang sederajat dengan sekolah lanjutan menengah pertama (SLTP) yang memiliki ciri Islam yang dikelola dan dikembangkan di bawah naungan 
Kementerian Agama Republik Indonesia. Sebagai lembaga pendidikan yang mempunyai ciri khas Islam, madrasah memegang peranan penting dalam proses pembentukan kepribadian anak didik, karena melalui pendidikan madrasah ini para orang tua berharap anak-anaknya memiliki dua kemampuan sekaligus, tidak hanya pengetahuan umum (IPTEK) tetapi juga memiliki kepribadian dan komitmen yang tinggi terhadap agamanya (IMTAQ) (https://mtsnurulburhan.wordperss.com).

Penelitian ini memfokuskan pada kinerja Guru pada Lembaga Pendidikan MTs Ma'arif di Kabupaten Banyumas. Alasannya karena sepanjang pengetahuan penulis penelitian manajemen pendidikan di MTs masih sangat jarang dilakukan selain itu kinerja Guru di Mts Ma'arif masih sangat rendah sehingga perlu dilakukan pengkajian lebih dalam.

Kinerja Guru MTs Ma'arif Kabupaten Banyumas yang masih rendah ini dibuktikan dengan peringkat nilai UN yang rendah. Peringkat UN yang rendah ini menunjukan bahwa kinerja Guru MTs Ma'arif dalam proses pembelajaran masih sangat rendah. Kinerja guru dapat mempengaruhi hasil belajar siswa. Berdasarkan penelitian yang dilakukan oleh Asmawati (2016) menunjukan bahwa Kinerja guru mempengaruhi peningkatan hasil belajar siswa. Selain itu juga disebutkan bahwa semakin besar usaha guru dalam aspek perencanaan, pelaksanaan, dan evaluasi pembelajaran, semakin besar peluang guru untuk meningkatkan hasil belajar siswa dan pengalaman mengajar guru turut memberikan kontribusi untuk meningkatkan hasil belajar siswa begitu juga sebaliknya. Juga pada penelitian yang dilakukan oleh Wasimah (2015) menunjukan bahwa kinerja guru berpengaruh signifikan terhadap hasil belajar siswa.

Di Kabupaten Banyumas terdapat 206 sekolah SMP/MTs, 159 Sekolah SMP dan 47 Sekolah MTs. Dari 47 sekolah MTs sebanyak 57\% atau 27 sekolah adalah Mts Ma'arif NU. Berdasarkan data Musyawarah Kerja Kepala Sekolah (MKKS) Sub Rayon 01 SMP Kabupaten Banyumas Peringkat UN Tahun Pelajaran 2017/2018 MTs Ma'arif berada di Peringkat terbawah. Hal ini dapat dilihat pada Tabel berikut:

Tabel 1. Peringkat UN MTs Ma'arif NU Kabupaten Banyumas Tahun Pelajaran 2017/2018

\begin{tabular}{llll}
\hline No & Nama Sekolah & Siswa
\end{tabular}

\begin{tabular}{clcc}
\hline 1 & MTs Manu 1 Cilongok & 230 & 63 \\
2 & MTs Manu 1 Kebasen & 181 & 70 \\
3 & MTs Manu 2 Cilongok & 157 & 76 \\
4 & MTs Manu Karanglewas & 109 & 87 \\
5 & MTs. Manu 1 Kemranjen & 147 & 95 \\
6 & MTs Manu Pekuncen & 181 & 100 \\
7 & MTs Manu 1 Ajibarang & 170 & 104 \\
8 & MTs Manu Sumbang & 104 & 107 \\
9 & MTs. Manu 1 Sumpiuh & 205 & 108 \\
10 & MTs Manu 1 Patikraja & 111 & 110 \\
11 & MTs Manu Kedungbanteng & 73 & 124 \\
12 & MTS Manu 1 Gumelar & 45 & 125 \\
13 & MTs. Manu 4 Kemranjen & 45 & 133 \\
14 & MTs. Manu 3 Kemranjen & 72 & 134 \\
15 & MTs. Manu 2 Kemranjen & 74 & 162 \\
16 & MTs. Manu 2 Sumpiuh & 39 & 166 \\
17 & MTs Manu Kembaran & 109 & 173 \\
18 & MTs. Manu 1 Tambak & 20 & 182 \\
\hline
\end{tabular}




\begin{tabular}{llcl}
\hline 19 & MTs Manu Sokaraja & 79 & 186 \\
20 & Mts Maarif NU 1 Pwt barat & 87 & 196 \\
21 & MTs Manu 2 Ajibarang & & 197 \\
22 & MTS Manu 1 Pekuncen & 181 & 198 \\
23 & MTs Manu Purwojaati & 50 & 199 \\
24 & MTs Manu Al-Muhahidin & 33 & 200 \\
25 & MTs Manu 1 Rawalo & 102 & 203 \\
26 & MTs Manu 2 Rawalo & 55 & 204 \\
27 & MTs Manu 1 Lumbir & 49 & 205 \\
\hline
\end{tabular}

Sumber: Data sekolah di bawah naungan LP Ma'arif NU

Selain rendahnya kinerja Guru dalam proses pembelajaran, banyak juga Guru yang masih kurang kompeten dalam merencanakan proses pembelajaran dan belum adanya pembagian tugas dan wewenang kepada Guru secara merata. Iklim sekolah yang kurang kondusif sehingga menimbulkan jarak dan kurang harmonisnya hubungan antar Guru hal ini berdampak pada kinerja Guru dan tidak sedikit pula jumlah Guru yang kurang mampu dalam melaksanakan proses pembelajaran.

Dari sekian banyaknya Guru yang mengajar, banyak Guru mengajarkan mata pelajaran yang tidak sesuai dengan latar belakang pendidikan yang dimilikinya. Juga kurangnya sarana dan fasilitas di sekolah yang menyebabkan kinerja Guru menjadi rendah. Kondisi ini memerlukan adanya peningkatan kinerja Guru agar meningkatkan kualitas pendidikan khususnya Mts Ma'arif NU di Kabupaten Banyumas.

Berdasarkan uraian di atas, maka peneliti tertarik untuk mengetahui pengaruh gaya kepemimpinan transformasional Kepala Sekolah, iklim sekolah dan komitmen profesional terhadap kinerja guru (Studi Kasus di MTs Ma'arif NU Kabupaten Banyumas).

\section{METODE ANALISIS}

\section{Populasi dan Teknik Pengambilan Sampel}

Dalam penelitian ini yang akan dijadikan populasi adalah Guru MTs Ma'arif NU di Kabupaten Banyumas. Jumlah Guru MTs Ma'arif NU se Kabupaten Banyumas sebanyak 662 orang yang terdiri atas Guru PNS, Guru Tetap Yayasan dan Guru Tidak Tetap.

Sampel adalah bagian dari jumlah dari karakteristik yang dimiliki oleh populasi tersebut. Bila populasi besar dan peneliti tidak mungkin mempelajari semua yang ada pada populasi maka peneliti dapat menggunakan sampel yang diambil dari populasi itu. Populasi Guru MTs Ma'arif NU se Kabupaten Banyumas adalah 662 orang. Presisi ditetapkan 5\% (dengan tingkat konfidensi 95\%). Sampel yang diperlukan dengan perhitungan sebagai berikut:

$$
\begin{aligned}
& \mathrm{n}=\frac{\mathrm{N}}{\mathrm{Nd}^{2}+1(662 \times 0,0025)+1} \quad 1,655+1=\underline{662}=\underline{2,655}=\underline{62} \\
& =249,34
\end{aligned}
$$

Jumlah sampel yang diambil adalah 249 orang.

Teknik pengambilan sampel yang digunakan dalam penelitian ini menggunakan teknik pengambilan Random Sampling. Teknik Random sampling adalah teknik pengambilan sampel dari populasi yang dilakukan secara acak tanpa memperhatikan strata yang ada dalam populasi (Sugiyono, 2010).

\section{Metode Pengumpulan Data}

Sumber data yang digunakan dalam penelitian ini adalah data primer. Data primer yang dilakukan dengan mengunakan kuesioner atau angket yang mendukung dan disesuaikan 
dengan tema penelitian. Metode pengumpulan data yang digunakan dalam penelitian ini adalah kuesioner.

\section{Definisi Operasional Variabel}

\section{Gaya Kepemimpinan Transformasional Kepala Sekolah}

Gaya kepemimpinan kepala sekolah dalam mempengaruhi kinerja Guru melalui penciptaan iklim sekolah yang baik dan profesionalisme kebijakan Guru berupa Peraturan dan keputusankeputusan yang dibuat oleh kepala sekolah dalam rangka meningkatkan kinerja bawahannya (Guru).

\section{Iklim Sekolah}

Iklim sekolah dapat dilihat dari faktor seperti kurikulum, sarana, dan kepemimpinan kepala sekolah dan pembelajaran lingkungan pembelajaran di kelas. Iklim yang kondusif ditandai dengan terciptanya lingkungan belajar yang aman, nyaman, dan tertib sehingga pembelajaran dapat berlangsung dengan efektif.

\section{Komitmen Profesional Guru}

Iklim sekolah dapat dilihat dari faktor seperti kurikulum, sarana, dan kepemimpinan kepala sekolah dan pembelajaran lingkungan pembelajaran di kelas. Iklim yang kondusif ditandai dengan terciptanya lingkungan belajar yang aman, nyaman, dan tertib sehingga pembelajaran dapat berlangsung dengan efektif.

\section{Kinerja guru}

Kemampuan atau prestasi Guru dalam mengoptimalkan dan meningkatkan kualitas pendidikan.

\section{Alat Analisis Data}

Metode analisis data yang digunakan dalam penelitian ini adalah analisis regresi berganda menggunakan SPSS versi 24.0. Analisis regresi adalah suatu teknik untuk membangun persamaan dan menggunakan persamaan tersebut untuk membuat perkiraan.

\section{HASIL PENELITIAN}

Pengaruh Gaya Kepemimpinan Transformasional Kepala sekolah (X1) terhadap Iklim Sekolah (X2)

Tabel 2. pengaruh gaya kepemimpinan transformasional kepala sekolah (X1) terhadap iklim sekolah (X2)

\begin{tabular}{ccccccc}
\hline Variabel & $\mathrm{R}$ & $\begin{array}{c}\text { Koefisien } \\
\text { Determinan } \\
\left(\mathrm{R}^{2}\right)\end{array}$ & $\begin{array}{c}\text { Adjusted } \mathrm{R} \\
\text { Square }\end{array}$ & $\mathrm{B}$ & $\mathrm{F}_{\text {hitung }}$ & Sig. \\
\hline $\mathrm{X} 1-\mathrm{X} 2$ & 0,245 & 0,060 & 0,056 & 0,081 & 15,725 & 0,000 \\
\hline
\end{tabular}

Sumber: Data diolah (2019)

Berdasarkan Tabel 2 didapatkan nilai koefisien determinan $\left(\mathrm{R}^{2}\right)$ yakni 0,060, hal ini menunjukkan variabel gaya kepemimpinan transformasional kepala sekolah (X1) memberikan sumbangan efektif terhadap iklim sekolah (X2) 0,60\%. Sementara sisanya sebesar 99,4\% dipengaruhi oleh variabel lain yang tidak diteliti dalam penelitian ini. Dari hasil perhitungan di atas menunjukkan bahwa gaya kepemimpinan kepala sekolah berpengaruh secara positif dan signifikan terhadap iklim sekolah dengan nilai sig. $=0,000$ yakni $<0,05$. Dengan demikian hipotesis pertama yang menyatakan "gaya kepemimpinan transformasional kepala sekolah (X1) berpengaruh positif dan signifikan terhadap iklim sekolah (X2)" diterima.

Pengaruh gaya kepemimpinan transformasional kepala sekolah (X1) terhadap komitmen profesional guru (X3)

Tabel 3. pengaruh gaya kepemimpinan transformasional kepala sekolah (X1) terhadap komitmen profesional guru (X3)

\begin{tabular}{llcclcc} 
Variabel & $\mathrm{R}$ & $\begin{array}{c}\text { Koefisien } \\
\text { Determinan }\end{array}$ & $\begin{array}{c}\text { Adjusted R } \\
\text { Square }\end{array}$ & $\mathrm{B}$ & $\mathrm{F}_{\text {hitung }}$ & Sig. \\
\hline
\end{tabular}




\begin{tabular}{ccccccc}
\hline \multicolumn{7}{c}{$\left(\mathrm{R}^{2}\right)$} \\
$\mathrm{X} 1-\mathrm{X3}$ & 0,574 & 0,330 & 0,327 & 0,337 & 121,488 & 0,000 \\
\hline
\end{tabular}

Sumber: Data diolah (2019)

Berdasarkan Tabel 3 didapatkan nilai koefisien determinan $\left(\mathrm{R}^{2}\right)$ yakni 0,330 , hal ini menunjukkan variabel gaya kepemimpinan transformasional kepala sekolah (X1) memberikan sumbangan efektif terhadap komitmen profesional guru (X3) 33,0\%. Sementara sisanya sebesar $77,0 \%$ dipengaruhi oleh variabel lain yang tidak diteliti dalam penelitian ini. Dari hasil perhitungan di atas menunjukkan bahwa kepala sekolah berpengaruh secara positif dan signifikan terhadap komitmen profesional guru dengan nilai sig. $=0,000$ yakni $<0,05$. Dengan demikian hipotesis kedua yang menyatakan "gaya kepemimpinan transformasional kepala sekolah (X1) berpengaruh positif dan signifikan terhadap komitmen profesional guru (X3)" diterima.

Pengaruh Iklim Sekolah (X2) terhadap Kinerja Guru (Y)

Tabel 4. Iklim Sekolah (X2) terhadap Kinerja Guru (Y)

\begin{tabular}{ccccccc}
\hline Variabel & $\mathrm{R}$ & $\begin{array}{c}\text { Koefisien } \\
\text { Determinan } \\
\left(\mathrm{R}^{2}\right)\end{array}$ & $\begin{array}{c}\text { Adjusted R } \\
\text { Square }\end{array}$ & $\mathrm{B}$ & $\mathrm{F}_{\text {hitung }}$ & Sig. \\
\hline $\mathrm{X} 2-\mathrm{Y}$ & 0,187 & 0,035 & 0,031 & 0,225 & 8,935 & 0,003 \\
\hline
\end{tabular}

Sumber: Data diolah (2019)

Berdasarkan Tabel 4 didapatkan nilai koefisien determinan $\left(R^{2}\right)$ yakni 0,035 , hal ini menunjukkan variabel iklim sekolah (X2) memberikan sumbangan efektif terhadap kinerja guru (Y) 0,35\%. Sementara sisanya sebesar 99,65\% dipengaruhi oleh variabel lain yang tidak diteliti dalam penelitian ini. Dari hasil perhitungan di atas menunjukkan bahwa iklim sekolah berpengaruh secara positif dan signifikan terhadap kinerja guru dengan nilai sig. $=0,003$ yakni $<0,05$. Dengan demikian hipotesis ketiga yang menyatakan "iklim sekolah (M1) berpengaruh positif dan signifikan terhadap kineja guru (Y)" diterima.

Pengaruh Komitmen Profesional Guru (X3) terhadap Kinerja Guru (Y)

Tabel 5. Komitmen Profesional Guru (X3) terhadap Kinerja Guru (Y)

\begin{tabular}{ccccccc}
\hline Variabel & $\mathrm{R}$ & $\begin{array}{c}\text { Koefisien } \\
\text { Determinan } \\
\left(\mathrm{R}^{2}\right)\end{array}$ & $\begin{array}{c}\text { Adjusted R } \\
\text { Square }\end{array}$ & $\mathrm{B}$ & $\mathrm{F}_{\text {hitung }}$ & Sig. \\
\hline $\mathrm{X} 3-\mathrm{Y}$ & 0,427 & 0,183 & 0,179 & 0,291 & 55,229 & 0,000 \\
\hline
\end{tabular}

Sumber: Data diolah (2019)

Berdasarkan Tabel 5 didapatkan nilai koefisien determinan $\left(\mathrm{R}^{2}\right)$ yakni 0,183, hal ini menunjukkan variabel komitmen profesional guru (X3) memberikan sumbangan efektif terhadap kinerja guru (Y) 18,3\%. Sementara sisanya sebesar $81,7 \%$ dipengaruhi oleh variabel lain yang tidak diteliti dalam penelitian ini. Dari hasil perhitungan di atas menunjukkan bahwa komitmen profesional guru berpengaruh secara positif dan signifikan terhadap kinerja guru dengan nilai sig. $=0,000$ yakni $<0,05$. Dengan demikian hipotesis keempat yang menyatakan "komitmen profesional guru (X3) berpengaruh positif dan signifikan terhadap kineja guru (Y)" diterima.

Pengaruh Gaya Kepemimpinan Transformasional Kepala Sekolah (X1) terhadap Kinerja Guru (Y)

Tabel 6. Gaya Kepemimpinan Transformasional Kepala Sekolah (X1) terhadap Kinerja Guru (Y)

\begin{tabular}{ccccccc}
\hline Variabel & $\mathrm{R}$ & $\begin{array}{c}\text { Koefisien } \\
\text { Determinan } \\
\left(\mathrm{R}^{2}\right)\end{array}$ & $\begin{array}{c}\text { Adjusted } \mathrm{R} \\
\text { Square }\end{array}$ & $\mathrm{B}$ & $\mathrm{F}_{\text {hitung }}$ & Sig. \\
\hline $\mathrm{X} 1-\mathrm{Y}$ & 0,386 & 0,149 & 0,145 & 0,154 & 43,175 & 0,000 \\
\hline
\end{tabular}

Sumber: Data di olah (2019) 
Berdasarkan Tabel 6 didapatkan nilai koefisien determinan $\left(\mathrm{R}^{2}\right)$ yakni 0,149, hal ini menunjukkan variabel gaya kepemimpinan (X1) memberikan sumbangan efektif terhadap kinerja guru (Y) 14,9\%. Sementara sisanya sebesar 85,1\% dipengaruhi oleh variabel lain yang tidak diteliti dalam penelitian ini. Dari hasil perhitungan di atas menunjukkan bahwa gaya kepemimpinan transformasional kepala sekolah berpengaruh secara positif dan signifikan terhadap kinerja guru dengan nilai sig. $=0,000$ yakni $<0,05$. Dengan demikian hipotesis kelima yang menyatakan "gaya kepemimpinan transformasional kepala sekolah (X) berpengaruh positif dan signifikan terhadap kineja guru (Y)" diterima.

\section{PEMBAHASAN}

\section{Gaya Kepemimpinan transformasional Kepala Sekolah (X1) berpengaruh positif terhadap Iklim Sekolah (X2)}

Hasil pengujian hipotesis menunjukkan bahwa gaya kepemimpinan transformasional kepala sekolah berpengaruh positif dan signifikan terhadap iklim sekolah. Artinya perilaku pemimpin yang menggunakan gaya kepemimpinan transformasional kepala sekolah dapat memberikan pengaruh yang baik terhadap iklim sekolah di MTs Ma'arif NU Kabupaten Banyumas. Berdasarkan analisis deskriptif variabel iklim sekolah diperoleh nilai minimum responden dari jawaban kuesioner sebesar 21 dan nilai maksimum 38. Nilai mean 28,14 dan nilai standar deviasi atau penyebaran data sebesar 3,60. Hasil ststistik deskriptif menunjukan bahwa nilai mean lebih besar dibandingkan dengan nilai standar deviasi. Nilai mean yang lebih tinggi menunjukan representasi yang baik untuk penyebaran data.

Berdasarkan hasil analisis statistik di atas menunjukkan bahwa responden memiliki persepsi positif terhadap iklim sekolah, menurut responden kepala sekolah mampu menciptakan suasana kekeluargaan yang sangat akrab sehingga guru merasa nyaman berada di sekolah. Gaya kepemimpinan kepala sekolah yang efektif dapat menciptakan iklim sekolah yang kondusif. Iklim sekolah yang kondusif dapat menciptakan suasana yang aman dan nyaman bagi guru dan seluruh warga sekolah dalam menjalankan aktivtas belajar mengajar dan belajar bagi siswa. Sehingga diharapkan dengan terciptanya iklim kerja yang kondusif dapat meningkatkan kinerja Guru. Adanya pengaruh gaya kepemimpinan transformasional kepala sekolah terhadap iklim sekolah didukung penelitian sebelumnya yang dilakukan oleh Aminullah, Tripalupi dan Dunia (2014) dan Fitri dan Syamsir (2011) yang menyebutkan bahwa gaya kepemimpinan kepala sekolah berpengaruh terhadap iklim organisasi meskipun pengaruh yang diberikan sangat kecil.

\section{Gaya Kepemimpinan transformasional Kepala Sekolah (X1) berpengaruh positif terhadap komitmen profesional Guru (X3)}

Hasil pengujian hipotesis menunjukkan bahwa gaya kepemimpinan transformasional kepala sekolah berpengaruh positif dan signifikan terhadap komitmen profesional guru. Artinya perilaku pemimpin yang menggunakan gaya kepemimpinan transformasional dapat memberikan pengaruh yang baik terhadap komitmen profesional guru MTs Ma'arif NU Kabupaten Banyumas. Berdasarkan analisis deskriptif variabel komitmen profesional diperoleh nilai minimum responden dari jawaban kuesioner sebesar 40 dan nilai maksimum 72 . Nilai mean 55,08 dan nilai standar deviasi atau penyebaran data sebesar 6,36. Hasil ststistik deskriptif menunjukan bahwa nilai mean lebih besar dibandingkan dengan nilai standar deviasi. Nilai mean yang lebih tinggi menunjukan representasi yang baik untuk penyebaran data.

Berdasarkan hasil analisis statistik deskriptif, menunjukkan bahwa responden memiliki persepsi positif terhadap komitmen profesional guru di MTs Ma'arif NU Kabupaten Banyumas menurut responden, responden merasa sangat puas dengan gaya kepemimpinan transformasional kepala sekolah dimana komunikasi antar pimpinan dan bawahan terjalin baik, pemimpin ini juga selalu memberikan motivasi dan bimbingan kepada bawahan, mendengarkan keluhan dan kendala yang dihadapi bawahan dalam pencapaian target sehingga bawahan merasa memiliki terhadap lembaga sekolah dan merasa bahwa sekolah merupakan bagian dari kehidupannya. Adanya pengaruh gaya kepemimpinan transformasional kepala sekolah terhadap komitmen profesional mendukung penelitian sebelumnya yang dilakukan oleh 
Cahyani, Sonhadji dan Arifin (2016), A. Fathoni (2018), Fahmi (2017) daan Sari (2018) yang menunjukan bahwa gaya kepemimpinan transformasional kepala sekolah berpengaruh terhadap komitmen profesional guru.

\section{Iklim sekolah (X2) berpengaruh positif terhadap kinerja Guru (Y)}

Hasil pengujian hipotesis menunjukkan bahwa iklim sekolah berpengaruh positif dan signifikan terhadap kinerja guru. Artinya iklim sekolah yang baik dapat memberikan pengaruh yang baik terhadap kinerja guru MTs Ma'arif NU Kabupaten Banyumas. Berdasarkan analisis deskriptif pada variabel kinerja guru, diperoleh nilai minimum responden dari jawaban kuesioner sebesar 30 dan nilai maksimum 49. Nilai mean 38,20 dan nilai standar deviasi atau penyebaran data sebesar 4,33. Hasil ststistik deskriptif menunjukan bahwa nilai mean lebih besar dibandingkan dengan nilai standar deviasi. Nilai mean yang lebih tinggi menunjukan representasi yang baik untuk penyebaran data.

Berdasarkan hasil analisis statistik deskriptif, menunjukkan bahwa responden memiliki persepsi positif terhadap kinerja guru di MTs Ma'arif NU Kabupaten Banyumas menurut responden, responden merasa sangat puas dengan iklim sekolah yang dibangun, lingkungan yang ramah, hubungan yang baik antara kepala sekolah dan sesama guru juga seluruh warga sekolah memberikan pengaruh untuk meningkatkan kinerja. Selain itu fasilitas sekolah yang lengkap yang menunjang kesuksesan kinerja juga tersedia. Adanya pengaruh gaya iklim sekolah terhadap kineja guru mendukung penelitian sebelumnya yang dilakukan oleh Mijo (2006) Hantono (2015), Arifin (2018), Rahmawati (2011) dan Septianty R (2016) yang menunjukan bahwa terdapat pengaruh iklim sekolah terhadap kinerja guru

\section{Komitmen Profesional Guru (X3) berpengaruh positif terhadap kinerja Guru (Y)}

Hasil pengujian hipotesis menunjukkan bahwa komitmen profesional guru berpengaruh positif dan signifikan terhadap kinerja guru. Artinya komitmen profesional guru yang tinggi dapat memberikan pengaruh yang baik terhadap kinerja guru MTs Ma'arif NU Kabupaten Banyumas.

Berdasarkan analisis deskriptif pada variabel kinerja guru diperoleh nilai minimum responden dari jawaban kuesioner sebesar 30 dan nilai maksimum 49. Nilai mean 38,20 dan nilai standar deviasi atau penyebaran data sebesar 4,33. Hasil ststistik deskriptif menunjukan bahwa nilai mean lebih besar dibandingkan dengan nilai standar deviasi. Nilai mean yang lebih tinggi menunjukan representasi yang baik untuk penyebaran data.

Berdasarkan hasil analisis statistik deskriptif, menunjukkan bahwa responden memiliki persepsi positif terhadap kinerja guru di MTs Ma'arif NU Kabupaten Banyumas menurut responden, responden merasa bahwa sekolah ini merupakan bagian dari kehidupannya dan akan tetap bertahan untuk bekerja di sekolah tersebut. Adanya rasa memiliki terhadap organisasi ini dapat meningkatkan kinerja guru. Adanya pengaruh komitmen profesional guru terhadap kineja guru mendukung penelitian sebelumnya yang dilakukan oleh Nurcahyani dan Yuniawan (2010), Sagie dan Krausz (2003) Cohen dan Kol, (2004), Hasbi (2016), Dewi (2015) dan Rachmawati (2014) yang menunjukan bahwa komitmen profesional guru berpengaruh terhadap kinerja guru.

\section{Gaya kepemimpinan transformasional kepala sekolah (X1) berpengaruh positif terhadap Kinerja Guru (Y)}

Hasil pengujian hipotesis menunjukkan bahwa gaya kepemimpinan kepala sekolah berpengaruh positif dan signifikan terhadap kinerja guru. Berdasarkan analisis deskriptif pada variabel kinerja guru diperoleh nilai minimum responden dari jawaban kuesioner sebesar 30 dan nilai maksimum 49. Nilai mean 38,20 dan nilai standar deviasi atau penyebaran data sebesar 4,33. Hasil ststistik deskriptif menunjukan bahwa nilai mean lebih besar dibandingkan dengan nilai standar deviasi. Nilai mean yang lebih tinggi menunjukan representasi yang baik untuk penyebaran data. Artinya gaya kepemimpinan transformasional kepala sekolah dapat memberikan pengaruh yang baik terhadap kinerja guru MTs Ma'arif NU Kabupaten Banyumas. Gaya kepemimpinan transformasioanl lebih dari sekedar pertukaran, melainkan memberikan dorongan pada bawahan untuk melakukan kinerja yang diharapkan dengan melakukan stimulasi intelektual dan menginspirasi para bawahan untuk melebihi minat-minat pribadi 
mereka demi tujuan, misi, dan visi kolektif yang lebih tinggi. Melalui gaya kepemimpinan yang efektif, seorang kepala sekolah dapat memonitor, mengendalikan, memperbaiki dan meningkatkan kinerja guru sesuai dengan tujuan, harapan, visi, dan misi yang diemban melalui sekolah. Adanya pengaruh gaya kepemimpinan transformasional kepala sekolah terhadap kineja guru mendukung penelitian sebelumnya yang dilakukan oleh Khairiziah, Noor dan Suprapto (2015), Andriyani (2016), Astuti (2015), Tampi (2014), Suwarni (2011), Saputra (2015) dan Rachmawati (2014) yang menunjukan bahwa gaya kepemimpinan transformasional kepala sekolah berpengaruh terhadap kinerja guru.

\section{KESIMPULAN}

Gaya kepemimpinan transformasional kepala sekolah berpengaruh positif dan signifikan terhadap iklim sekolah di MTs Ma'arif NU Kabupaten Banyumas. Adanya pengaruh tersebut menunjukkan bahwa perilaku gaya kepemimpinan transformasional yang baik yang dilakukan oleh kepala sekolah maka semakin baik iklim sekolah yang dirasakan di sekolah tersebut. Gaya kepemimpinan transformasional kepala sekolah berpengaruh positif dan signifikan terhadap komitmen profesional guru MTs Ma'arif NU di Kabupaten Banyumas. Adanya pengaruh tersebut menunjukkan bahwa perilaku gaya kepemimpinan transformasional yang baik yang dilakukan kepala sekolah maka semakin tinggi komitmen profesional guru.

Iklim Sekolah berpengaruh positif dan signifikan terhadap kinerja guru MTs Ma'arif NU Kabupaten Banyumas. Adanya pengaruh tersebut menunjukkan bahwa iklim sekolah yang baik makan akan semakin baik pula kinerja guru di MTs Ma'arif NU Kabupaten Banyumas. Komitmen profesional berpengaruh positif dan signifikan terhadap kinerja guru MTs Ma'arif NU Kabupaten Banyumas. Adanya pengaruh tersebut menunjukkan bahwa komitmen profesional yang tinggi akan membuat kinerja guru semakin baik. Gaya kepemimpinan transformasional kepala sekolah berpengaruh positif dan signifikan kinerja guru di MTs Ma'arif NU Kabupaten Banyumas. Adanya pengaruh tersebut menunjukkan bahwa perilaku gaya kepemimpinan transformasional yang baik yang dilakukan kepala sekolah maka semakin baik kinerja guru di MTs Ma'arif NU Kabupaten Banyumas.

\section{IMPLIKASI}

\section{Implikasi Teoritis}

Penelitian ini berhasil membuktikan bahwa kinerja guru dipengaruhi oleh gaya kepemimpinan transformasional kepala sekolah. Selain itu, penelitian ini juga membuktikan bahwa iklim sekolah, dan komitmen professional sebagai variabel mediasi yang mempengaruhi kinerja guru secara langsung maupun tidak langsung. Hasil penelitian dilakukan oleh Suwarni (2011) hasil penelitian menunjukan bahwa gaya kepemimpinan kepala sekolah berpengaruh positif dan signifikan terhadap kinerja guru.

\section{Implikasi Praktis}

Berdasarkan hasil penelitian ini, secara praktis dapat digunakan menjadi bahan referensi dan sebagai bahan masukan bagi guru-guru terutama di lingkungan MTs Ma'arif NU Kabupaten Banyumas untuk meningkatkan kualitas kinerja guru, sehingga kinerja guru menjadi semakin lebih baik dan komitmen guru dalam mengajar semakin lebih profesional. 


\section{DAFTAR PUSTAKA}

Ahyar Yuniawan, Nur Cahyani. (2010). Pengaruh Profesionalisme Pemeriksa Pajak, Kepuasan Kerja dan Komitmen Perusahaan Terhadap Kinerja Karyawan. Jurnal Bisnis dan Ekonomi, Vol 17, Issue 1.

Aminullah, Desian., Lulup Endah Tripalupi., I Ketut Dunia. (2014). Pengaruh Kepemimpinan Transformasional Kepala Sekolah pada SMP N 4 Negara, Vol I, No 1 Tahun 2014.

Arifin, Muh, Husein. (2018). Pengaruh Gaya Kepemimpinan Kepala Sekolah, Motivasi Berprestasi Dan Iklim Sekolah Terhadap Kinerja Guru Di Man 2 Kabupaten Probolinggo. Jurnal Pendidikan Ilmu Pengetahuan Sosial. Volum 3 Nomor 1 bulan Maret 2018 Page 1 3 p-ISSN: 2477-6254 e-ISSN: 2477-8427.

Astuti Yuyun Fitri. (2015). Pengaruh Gaya Kepemimpinan Transformasional dan Kompensasi terhadap Kinerja Karyawan pada Karyawan Pamella Supermarket 7. http://eprints.uny.ac.id/id/eprint/16357.

Cohen, Aaron dan Yardena Kol, (2004). "Profesionalism and Organizational Citizenship Behavior", Journal of Managerial Psichology, ABI/INFORM Global, Vol.19, No.4,pp.386405.

Emilia Suci, Syamsir, Pengaruh Gaya Kepemimpinan Terhadap Iklim Kerja Organisasi pada PT.PLN Cabang Solok, Demokrasi, Vol X, No.2,Tahun 2011, h.171.

Hantono. (2015). Pengaruh Current Ratio Dan Debt To Equity Ratio Terhadap Profitabilitas Pada Perusahaan Manufaktur Sektor Logam Dan Sejenisnya Yang Terdaftar Di Bursa Efek Indonesia Periode 2009 - 2013, Jurnal Wira Ekonomi Mikroskil Volume 5, No 1. April 2015.

Maya Sari Dewi. (2015). Pengaruh Kepuasaan Kerja Dan Komitmen Organisasional Terhadap Kinerja Pegawai Bank Kalsel. Junal wawasan manajemen vol. 3, nomor 3, oktober 2016. Universitas Lambung Mangkurat Banjarmasin.

Nur Cahyani, I Made dan Dewi Adnyani, I.G.A. (2016). Pengaruh Kompensasi dan Motivasi Terhadap Kinerja Karyawan Dengan Kepuasan Kerja Sebagai Variabel Intervening. EJurnal Manajemen Universitas Undayana.

R, Indira Septianty. (2016). Pengaruh Kepemimpinan Kepala Sekolah dan Iklim Sekolah Terhadap Kinerja Guru Sekolah Menengah Kejuruan Negeri (SMKN) 2 Kota Bengkulu, An-Nizom, Vol I, No. 3, Desember 2016.

Sagie, Abraham dan Moshe Krausz, (2003), "What Aspects of The Job Have Most Effect on Nurse", Human Resource Management Journal, ABI/INFORM Global, Vol.13, No.1, pp.4662.

Saputra, Endri., Sumadi., dan Miswar, Dedi. (2015). Pengaruh Gaya Kepemimpinan Kepala Sekolah dan Motivasi Kerja Guru Terhadap Kinerja Guru. Jurnal Fakultas Keguruan dan Ilmu Kependidikan Universitas Lampung.

Sari, Putri Desmala. (2018). Pengaruh kepemimpinan transformasional kepala sekolah dan motivasi kerja guru terhadap profesionalisme guru Ekonomi SMA di Kota Yogyakarta tahun 2017. Jurnal Sanata Dharma University. 
Setiyati, Sri. (2014). Pengaruh Kepemimpinan Kepala Sekolah Motivasi Kerja, dan Budaya Sekolah terhadap Kinerja Guru, Jurnal Pendidikan Teknologi dan Kejuruan, Volume 22, Nomor 2, Oktober 2014.

Sujak, Abi. (1999). Kepemimpinan Manager (Eksistensi dalam perilaku organisasi), Jakarta: PT. Gramedia.

Sutiadi. (2003). Motivasi Karyawan Dan Aktifitas Manajerial Kepemimpinan Terhadap Kinerja Karyawan. Pasca Sarjana, Universitas Brawijaya, Malang.

Suwarni. (2011). Pengaruh Gaya Kepemimpinan Kepala Sekolah terhadap Kinerja Guru Ekonomi, Jurnal Pendidikan Dan Pembelajaran, Volume 18, Nomor 2, Oktober 2011.

Tampi, Bryan Johanes. (2014). Pengaruh Gaya Kepemimpinan dan Motivasi Terhadap Kinerja Karyawan Pada PT. Bank Negara Indonesia, TBk (Regional Sales Manado), Journal "Acta Diurna" Volume III. No.4. Tahun 2014. 